\title{
Crustacean parasites of Leporinus affinis, an Anostomidae fish from the Brazilian Amazon
}

\author{
Crustáceos parasitos de Leporinus affinis, um Anostomidae da Amazônia \\ brasileira
}

Huann Carllo Gentil Vasconcelos; Júlio César Sá-Oliveira1; Débora da Conceição Oliveira Salomão; Marcos Tavares-Dias $2,3 *$ (1)

1Departamento de Biologia, Universidade Federal do Amapá - UNIFAP, Macapá, AP, Brasil ¿Embrapa Amapá, Macapá, AP, Brasil

${ }^{3}$ Programa de Pós-graduação em Biodiversidade Tropical - PPGBio, Universidade Federal do Amapá - UNIFAP, Macapá, AP, Brasil

How to cite: Vasconcelos HCG, Sá-Oliveira JC, Salomão DCO, Tavares-Dias M. Crustacean parasites of Leporinus affinis, an Anostomidae fish from the Brazilian Amazon. Braz J Vet Parasito/ 2020; 29(2): e001820. https://doi.org/10.1590/S1984-29612020040

\begin{abstract}
This study investigated the fauna of ectoparasitic crustaceans in Leporinus affinis from Reservoir Coaracy Nunes, in eastern Amazon (Brazil), as well as the parasite-host interactions. The mouth, gills and tegument of $50.9 \%$ of the fish examined were parasitized by Argulus chicomendesi, Ergasilus turucuyus and Excorallana berbicensis, and a total of 118 parasites were collected. The dominance was found for E. berbicensis and the higher infestation levels were caused by E. berbicensis on the body surface of the hosts, but E. turucuyus had the highest prevalence on the gills of this host. The cluster analysis revealed higher similarity in the infestations by $E$. berbicensis and A. chicomendesi in relation to infestation site in hosts. Host sex and relative condition factor (Kn) were not influenced by moderate parasitism, but the abundance of parasites presented negative correlation with weight and $\mathrm{Kn}$ of the fish. This is the first study on the parasites of L. affinis showing low species diversity, with moderate prevalence and low parasite abundance.
\end{abstract}

Keywords: Crustaceans, ectoparasites, infestation, freshwater fish.

\section{Resumo}

Este estudo investigou a fauna de crustáceos parasitos de Leporinus affinis do Reservatório Coaracy Nunes, na Amazônia oriental (Brasil), bem como a interação parasito-hospedeiro. A boca, brânquias e tegumento de 50.9\% dos peixes examinados estavam parasitados por Argulus chicomendesi, Ergasilus turucuyus e Excorallana berbicensis, e um total de 118 parasitos foram coletados. A dominância foi de $E$. berbicensis, e os maiores índices de infestação foram causados por E. berbicensis na superfície corporal dos hospedeiros, mas E. turucuyus teve a maior prevalência nas brânquias. Análises de grupamento evidenciaram maior similaridade no padrão de infestação de $E$. berbicensis e $A$. chicomendesi quanto ao sítio de infestação nos hospedeiros. O sexo dos hospedeiros e fator de condição relativo (Kn) não foram influenciados pelo moderado parasitismo, mas a abundância de parasitos apresentou correlação negativa com o peso e Kn dos peixes. Este é o primeiro estudo sobre parasitos de L. affinis, mostrando baixa diversidade de espécies, com moderada prevalência e baixa abundância parasitária.

Palavras-chave: Crustacea, ectoparasitos, infestação, peixe de água doce. 


\section{Introduction}

As parasites are an important part of the planet biodiversity, studies on fish parasite populations have increased considerably in the last decades (Poulin \& Morand, 2004; Guidelli et al., 2006, 2009; Fontana et al., 2012; Mikheev et al., 2015; Vasconcelos \& Tavares-Dias, 2016; Yamada et al., 2017; Walker et al., 2017). Parasites have important functions in natural and artificial ecosystems because the identification of areas with low and high parasite diversity is fundamental for understanding the functioning of ecosystems. Studies on fish parasites have also increased due to an increase in culture and commercialization of important species for aquaculture (Luque \& Poulin, 2007).

Over 7000 species of Crustacea are parasites, exploiting an enormous range of invertebrate and vertebrate hosts in marine and freshwaters, which have less complex life cycle than other major parasite taxa (Boxshall \& Hayes, 2019). In general, Branchiura Thorell, 1818, Copepoda Milne-Edwards, 1940 and Isopoda Latreille, 1871 are the major taxa of Crustacea that infest fish in Brazil. Crustaceans are a diverse group with representatives that parasitize freshwater, marine and brackish fish, and are mostly ectoparasites (Eiras et al., 2010; Lima et al., 2013; Luque et al., 2013; Vasconcelos \& Tavares-Dias, 2016). In Brazil, for freshwater fish Eiras et al. (2010) listed 118 species of crustaceans; Luque et al. (2013) listed 136 species of these parasites and; posteriorly, Tavares-Dias et al. (2015) reported 76 species of Branchiura, Copepoda and Isopoda parasitizing 119 fishes of different families distributed into 35 host genera. However, nothing is known about these parasites infesting Leporinus affinis Günther, 1864; an Anostomidae from the Amazon basin (Froese \& Pauly, 2019) that can be found in the Coaracy Nunes Hydroelectric Plant Reservoir, Araguari River system, belonging to the Atlantic Ocean basin.

With the construction of the Coaracy Nunes Hydroelectric Plant Reservoir in the State of Amapá (Brazil), the fish fauna underwent significant changes in its dynamics and composition, with an increase in the representativeness of opportunistic species and disappearance of other species, including rheophilic species, favoring the process of homogenization from fish fauna (Sá-Oliveira et al., 2013). However, knowledge about the fish parasites of the Coaracy Nunes Hydroelectric Plant Reservoir is yet scarce (Vasconcelos \& Tavares-Dias, 2016), indicating the need for greater effort in the search for this relevant knowledge. Thus, the aim of this study was to investigate the ectoparasitic crustacean fauna in L. affinis of the Coaracy Nunes Hydroelectric Plant Reservoir, in northern Brazil.

\section{Material and Methods}

\section{Study area and fish collection}

The Coaracy Nunes Hydroelectric Plant Reservoir (Figure 1) was constructed in the middle Araguari River, in the municipality of Ferreira Gomes (State of Amapá, Brazil) and has a drainage area of $23.5 \mathrm{~km}^{2}$ with a capacity of $138 \mathrm{Hm}^{3}$ and an average depth of $15 \mathrm{~m}$. Around the Coaracy Nunes Reservoir, there are two riverine communities

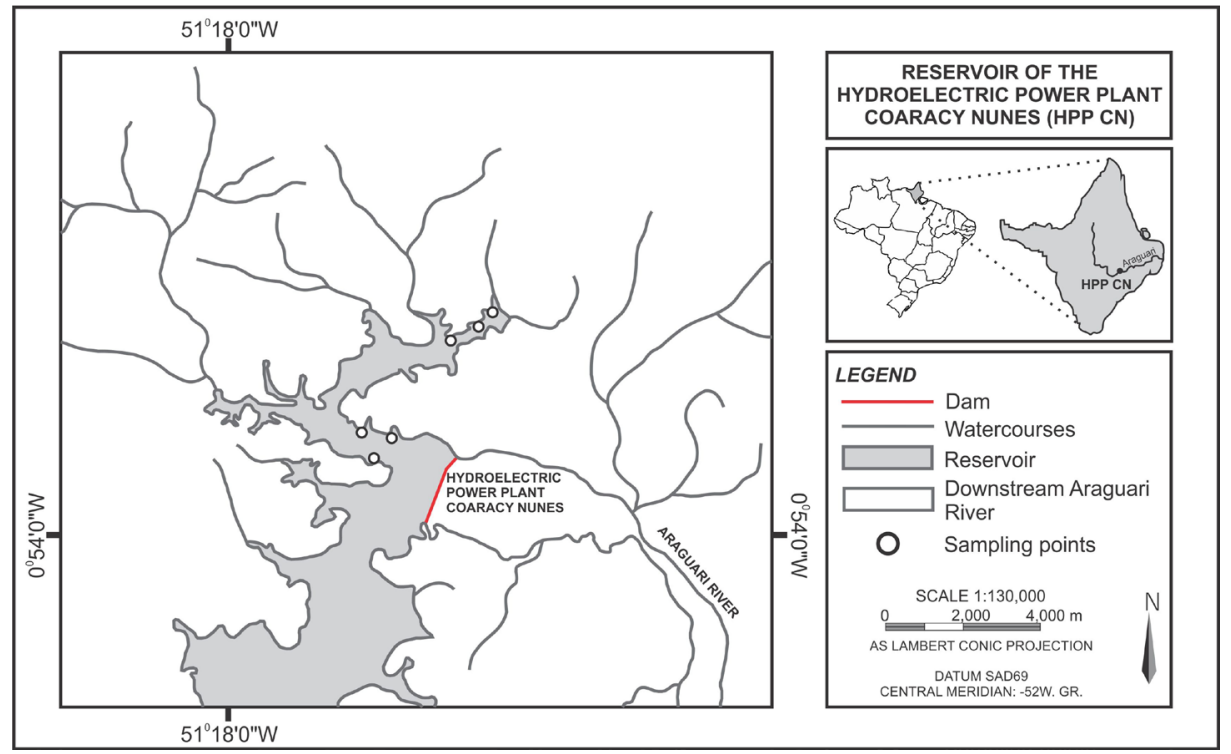

Figure 1. Collection sites of Leporinus affinis in Coaracy Nunes Reservoir, Araguari River basin, in eastern Amazon (Brazil). 
(Paredão and Caldeirão) associated with to agricultural areas and private properties for leisure and recreation (Sá-Oliveira et al., 2013). The reservoir has areas with few aquatic macrophytes, mainly Eichornia crassipes and Eleocharis sp., and a large amount of decaying arboreal vegetation due to non-deforestation.

In the Coaracy Nunes Hydroelectric Plant Reservoir (Figure 1), 53 specimens of $L$. affinis (22 males and 31 females) measuring $18.8 \pm 46.8 \mathrm{~cm}$ and weighing $121.1 \pm 100.5 \mathrm{~g}$ were collected bimonthly from October 2012 and August of 2013. For fish collection, we used gill nets with different mesh sizes $(20,30,40,50,60 \mathrm{~mm}$ between adjacent knots) (SISBIO License 35636-1). The time for each net was $12 \mathrm{~h}$ and the visits were every $2 \mathrm{~h}$.

Each fish caught was measured for standard length $(\mathrm{cm})$ and total weight $(\mathrm{g})$. Afterwards, the sex was macroscopically identified according to the methodology recommended by Vazzoler (1996). After collection, the fish were fixed in $10 \%$ formalin, and transported to the Laboratory of Ichthyology and Limnology from Universidade Federal do Amapá (UNIFAP), in Macapá city, State of Amapá (Brazil).

\section{Parasite collection and analysis}

At the fish sampling site, the mouth, tegument and fins of each fish were examined immediately after capture to verify the presence of ectoparasite crustaceans. The fish gills were collected, fixed in 5\%, formalin and examined with the aid of a stereomicroscope to collect and count the ectoparasites. The species of parasites recovered were then fixed in $70 \%$ alcohol, and conserved in solution of $70 \%$ alcohol and $10 \%$ glycerin and prepared for identification according to Eiras et al. (2006). The ecological terms used were those recommended by Bush et al. (1997) and dominance frequency (percentage of the infracommunities in which a parasite species is numerically dominant was according to Rohde et al. (1995).

Fish length and body weight were used to calculate the relative condition factor/Kn (Le Cren, 1951), which was compared between parasitized and non-parasitized fish using the t-test. The Spearman correlation coefficient ( $r s$ ) was used to determine possible correlations of parasite abundance with length, weight and Kn of hosts. G-test evaluated the effect of the host sex on the prevalence of parasites, and Mann-Whitney test (U), was employed to compare the abundance of parasite species between male and female hosts (Zar, 2010). The cluster analysis using Jaccard Similarity index between the infestation sites of the ectoparasite crustaceans in hosts. The clustering criterion chosen was the Ward method, which generates groups with the highest internal homogeneity and inter-group heterogeneity (Milligan \& Cooper, 1987).

\section{Results}

Among the 53 L. affinis examined, $50.9 \%$ were infested with one or more species of crustaceans. A total of 118 parasites were collected, being 17 Argulus chicomendesi Malta \& Varella, 2000 (Argulidae), 29 Ergasilus turucuyus Malta \& Varella, 1996 (Ergasilidae) and 72 Excorallana berbicensis Boone, 1918 (Corallanidae). For this reason, the dominance was observed for E. berbicensis (Table 1).

Table 1. Species of parasitic crustaceans in Leporinus affinis from the eastern Amazon (Brazil).

\begin{tabular}{cccccc}
\hline Parasites species & P (\%) & MA & MI & TNP & FD (\%) \\
\hline Argulus chicomendesi & 13.2 & $0.3 \pm 1.0$ & $2.4 \pm 1.8$ & 17 & 0.1 \\
Ergasilus turucuyus & 15.1 & $0.5 \pm 1.5$ & $3.6 \pm 2.1$ & 29 & 0.2 \\
Excorallana berbicensis & 37.7 & $1.4 \pm 2.4$ & $3.6 \pm 2.7$ & 72 & 0.6 \\
\hline
\end{tabular}

P: Prevalence; MA: Mean abundance; MI: Mean intensity; TNP: Total number of parasites; FD: Frequence of dominance.

Parasites were collected from the mouth, gills, and pectoral, pelvic, dorsal and anal fins, and tegument of hosts, but the predominant infestation site of $A$. chicomendesi and $E$. berbicensis was the tegument. Ergasilus turucuyus had gills as the predominant site of infestation (Figure 2). Jaccard cluster analysis showed greater similarity between A. chicomendesi and E. berbicensis infestation sites (Figure 3).

Prevalence and abundance of parasites crustacean in L. affinis was not influenced by the sex of the hosts (Table 2). In the examined fish, there was a predominance of non-parasitized hosts (Figure 4).

The relative condition factor $(\mathrm{Kn})$ differ $(\mathrm{t}=6.814 ; \mathrm{p}<0.0001)$ between parasitized $(\mathrm{Kn}=0.934 \pm 0.049)$ and non-parasitized hosts $(\mathrm{Kn}=1.052 \pm 0.071)$. The abundance of $A$. chicomendesi had a weak negative correlation 


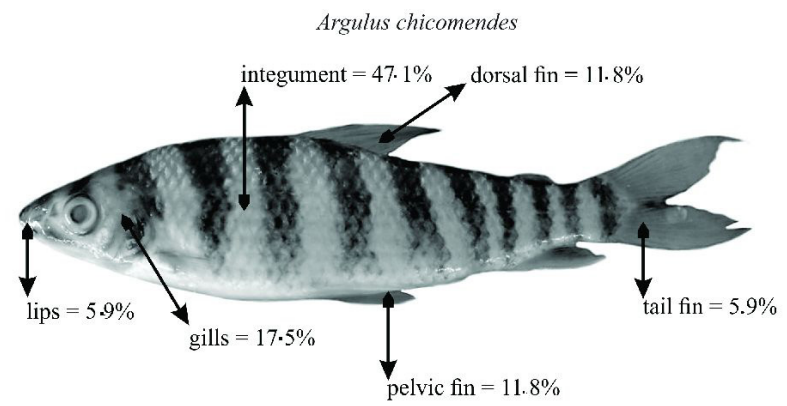

Excorallana berbicensis

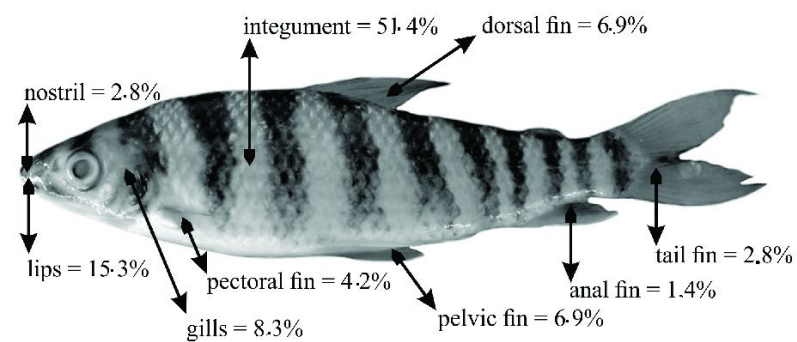

Ergasilus turucuyus

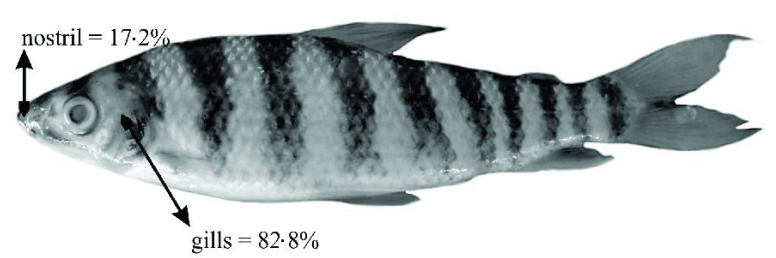

Figure 2. Prevalence of crustacean species by infestation sites in Leporinus affinis from the eastern Amazon (Brazil).

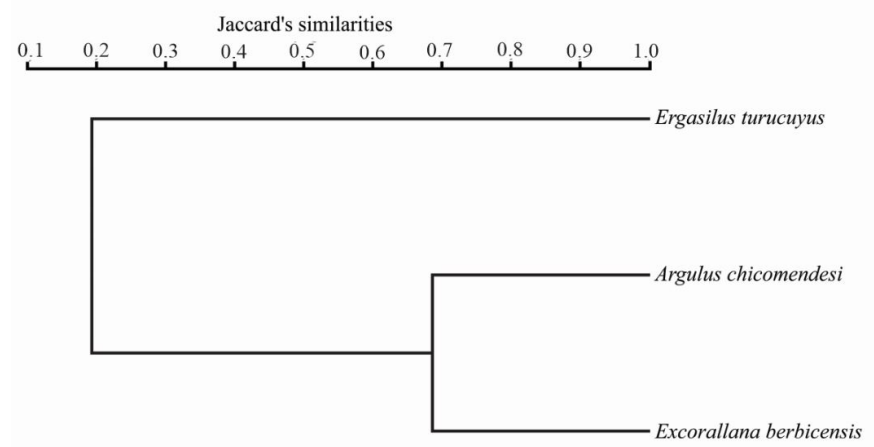

Figure 3. Cluster analysis using Jaccard index to sites of infestation of ectoparasites crustaceans in Leporinus affinis from the eastern Amazon (Brazil).

Table 2. Prevalence and abundance between sexes of Leporinus affinis from the eastern Amazon (Brazil).

\begin{tabular}{cccccc}
\hline \multirow{2}{*}{ Parasites species } & \multicolumn{2}{c}{ Prevalence } & & \multicolumn{3}{c}{ Abundance } \\
\cline { 2 - 3 } \cline { 5 - 6 } & $\mathbf{G}$ & $\mathbf{p}$ & $\mathbf{Z}$ & $\mathrm{p}$ \\
\hline Argulus chicomendesi & 0.006 & 0.737 & & 0.036 & 0.971 \\
Ergasilus turucuyus & 0.063 & 0.889 & & 0.144 & 0.885 \\
Excorallana berbicensis & 3.727 & 0.103 & & 1.471 & 0.141 \\
\hline
\end{tabular}

G: test G; Z: Mann-Whitney with normal approach of Z; p: value. 
Table 3. Spearman correlation coefficient ( $r s)$ of parasites abundance with the length, weight, relative condition factor (Kn) of Leporinus affinis from the eastern Amazon (Brazil).

\begin{tabular}{|c|c|c|c|c|c|c|}
\hline \multirow{2}{*}{ Parasites species } & \multicolumn{2}{|c|}{ Length } & \multicolumn{2}{|c|}{ Weight } & \multicolumn{2}{|c|}{ Kn } \\
\hline & rs & $p$ & $r s$ & $p$ & rs & $p$ \\
\hline Argulus chicomendesi & 0.036 & 0.799 & -0.148 & 0.292 & -0.366 & 0.007 \\
\hline Ergasilus turucuyus & -0.203 & 0.145 & -0.502 & 0.0001 & -0.622 & 0.0001 \\
\hline Excorallana berbicensis & -0.194 & 0.165 & -0.574 & 0.0001 & -0.7699 & 0.0001 \\
\hline
\end{tabular}

p: value.

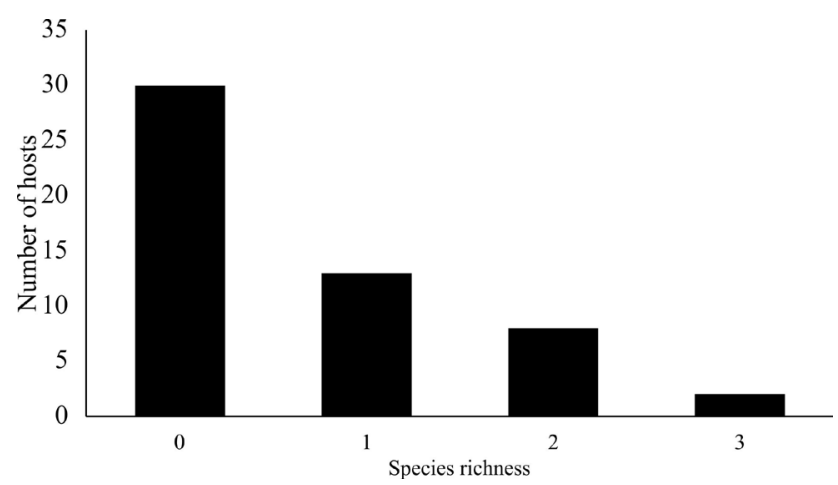

Figure 4. Species richness of parasites in Leporinus affinis from the eastern Amazon (Brazil).

with $\mathrm{Kn}$ of hosts. However, abundance of E. turucuyus and E. berbicensis presented a negative correlation with the $\mathrm{Kn}$ of hosts. The abundance of E. turucuyus and E. berbicensis presented a negative correlation with the weight of hosts. However, the abundance of the parasite species had not correlation with the length of hosts, as well the abundance of $A$. chicomendesi with the length and weight of hosts (Table 3 ).

\section{Discussion}

Understanding how communities of parasites are configured and their interactions within an ecosystem are among the basic goals of fish parasitology (Luque \& Poulin, 2007; Guidelli et al., 2009; Fontana et al., 2012; Vasconcelos \& Tavares-Dias, 2016; Yamada et al., 2017). The parasites-hosts systems constitute excellent study models on the essential aspects of ecology. The community of crustacean species parasitizing L. affinis was composed of E. berbicensis (Isopoda), A. chicomendesi (Argulidae) and E. turucuyus (Copepoda), but E. berbicensis was the dominant species. Similar results were reported for Acestrorhynchus falcirostris, Ageneiosus ucayalensis, Geophagus proximus, Hemiodus unimaculatus, Serrasalmus gibbus and Psectrogaster falcata from Coaracy Nunes Reservoir (Vasconcelos \& Tavares-Dias, 2016). This richness of crustacean parasite species has also been reported for other anostomid species, for example, Leporinus lacustris and Leporinus friderici from the upper Paraná River, in Brazil (Guidelli et al., 2006, 2009; Yamada et al., 2017). Furthermore, L. affinis had a low prevalence and low abundance of E. berbicensis, A. chicomendesi and E. turucuyus, similar to that was described for L. lacustris and L. friderici (Guidelli et al., 2006; Yamada et al., 2017). In contrast, prevalence and abundance were lower than for L. lacustris from the Paraná River (Guidelli et al., 2009). Nevertheless, levels of ectoparasitic crustacean infestations can be caused by a number of biotic factors (e.g. sex, body size, behavior and density, seasonality, host aggregation and parasites, among other factors) and abiotic factors (e.g. environmental conditions, temperature, seasonality, etc.) (Guidelli et al., 2009; Mikheev et al., 2015; Vasconcelos \& Tavares-Dias, 2016). However, there is yet limited information on the effects that parasitic crustaceans have on their hosts at a population level, as well as on the indirect effects that they may have on species that interact with their hosts, i.e. community level effects (Johnson et al., 2019). This is true particularly for A. chicomendesi, E. turucuyus and E. berbicensis, which infests Amazonian fish. However, it is presumed that when the crustaceans are abundant, severe pathology may occur in the host fish population.

The predominant infestation site of $A$. chicomendesi and $E$. berbicensis was the tegument of $L$. affinis, whereas E. turucuyus had gills as the predominant site of infestation; however, other sites were also infested. Similar pattern 
of distribution on hosts was also reported for A. falcirostris, A. ucayalensis, G. proximus, H. unimaculatus, S. gibbus and P. falcata from Coaracy Nunes Reservoir, State of Amapá (Vasconcelos \& Tavares-Dias, 2016). Van Name (1936) found E. berbicensis in gills and tegument of Lycengraulis grossidens in Guyana. Malta \& Varella (1996) described E. turucuyus in gills of $A$. falcirostris and A. falcatus from the Pacaás Novos River, in State of Rondônia, northern Brazil. Some parasitic crustacean species have preference by sites on host fish, while other parasites frequently have no preference. Both feeding and attachment sites probably play an important role in the distribution of crustacean species on host fish (Tavares-Dias et al., 2015). This coexistence of potentially competing species of parasites seem be facilitated by exploration of different sites on $L$. affinis, may reduce the competition by resources. Nevertheless, the lack of experimental systems that are easy to control and to manipulate accurately makes it difficult to determinate of the reasons from preference by sites on hosts for a single crustacean species, as well as together with other species.

Host sex may also be a determining factor in parasite infestation levels; thus, it has been evaluated in some studies on crustacean parasites (Guidelli et al., 2009; Vasconcelos \& Tavares-Dias, 2016). In L. affinis, the sex did not influence the infestation levels by ectoparasitic crustaceans in host populations. Similar results have been reported for L. lacustris infested with Gamispatulus schizodontis (Guidelli et al., 2009) and A. falcirostris, A. ucayalensis, G. proximus, H. unimaculatus, S. gibbus and P. falcata infested with A. chicomendesi, E. berbicensis and E. turucuyus (Vasconcelos \& Tavares-Dias, 2016).

The body size of the host, an indication of its age, may also be another factor influencing the abundance of parasites in host fish populations (Gomiero et al., 2012; Fontana et al., 2012; Walker et al., 2017). However, this was not observed in L. affinis, since the abundance of A. chicomendesi, E. berbicensis and E. turucuyus had not correlation with length, but only the weight of hosts. In L. affinis, only the abundance of E. turucuyus and E. berbicensis decreased with increasing weight of hosts. Similar findings were reported for Pygocentrus nattereri and Serrasalmus maculatus infested with Dolops bidentata and Dolops sp. (Fontana et al., 2012) and for Astyanax intermedius infested with Paracymothoa astyanaxi (Gomiero et al., 2012). The body condition of fish may be expressed by the weight-length relationship and constitutes the condition factor of the individual and population. The condition factor is therefore a quantitative indicator of the health status and body condition of fish, reflecting recent environmental and nutritional conditions, or even the effect of parasitism in hosts (Guidelli et al., 2009; Fontana et al., 2012; Vasconcelos \& Tavares-Dias, 2016). The condition factor of $L$. affinis decreased with increasing abundance of $A$. chicomendesi, E. berbicensis and E. turucuyus, indicating the impairment of host body conditions. Possibly, these effects on body conditions in L. affinis may have been influenced by lesions caused by parasites mainly in the mouth, gills and base of the fins. In host fish, the action of parasitic crustaceans may be direct, due to spoliation caused by their oral and modified appendages in powerful attachment organs (Fontana et al., 2012; Vasconcelos \& Tavares-Dias, 2016).

In conclusion, in L. affinis, the community of crustaceans was composed only of $A$. chicomendesi, E. turucuyus and E. berbicensis; however, A. chicomendesi and $E$. berbicensis had similarity for infestation sites in contrast to $E$. turucuyus. The moderate levels of infestations of these crustacean parasites negatively affected host body conditions, but host sex was not a determinant factor in parasite abundance. This was the first report of $A$. chicomendesi, E. turucuyus and $E$. berbicensis for L. affinis.

\section{Acknowledgements}

The authors thank the National Council for Scientific and Technological Development (Conselho Nacional de Desenvolvimento Científico e Tecnológico, CNPq), Brazil for the research productivity grant to M. Tavares-Dias (Grant n 303013/2015-0).

\section{References}

Boxshall G, Hayes P. Biodiversity and taxonomy of the parasitic Crustacea. In: Smit N, Bruce N, Hadfield K, editors. Parasitic Crustacea. Cham: Springer; 2019. p. 73-134. (Zoological Monographs; vol. 3). http://dx.doi.org/10.1007/978-3-030-17385-2_3.

Bush AO, Lafferty KD, Lotz JM, Shostak AW. Parasitology meets ecology on its own terms: margolis et al. revisited. J Parasitol 1997; 83(4): 575-583. http://dx.doi.org/10.2307/3284227. PMid:9267395.

Eiras JC, Takemoto RM, Pavanelli GC. Métodos de estudo e técnicas laboratoriais em parasitologia de peixes. Maringá: Eduem; 2006.

Eiras JC, Takemoto RM, Pavanelli GC. Diversidade dos parasitas de peixes de água doce do Brasil. Maringá: Editora Clichetec; 2010. 
Fontana M, Takemoto RM, Malta JCO, Mateus LAF. Parasitism by argulids (Crustacea: Branchiura) in piranhas (Osteichthyes: Serrasalmidae) captured in the Caiçara bays, upper Paraguay River, Pantanal, Mato Grosso State, Brazil. Neotrop Ichthyol 2012; 10(3): 653-659. http://dx.doi.org/10.1590/S1679-62252012005000019.

Froese R, Pauly D, editors. FishBase: version 12/2019 [online]. 2019 [cited 2019 Dec 17]. Available from: www.fishbase.org

Gomiero LM, Souza UP, Braga FMS. Condition factor of Astyanax intermedius Eigenmann, 1908 (Osteichthyes, Characidae) parasitised by Paracymothoa astyanaxi Lemos de Castro, 1955 (Crustacea, Cymothoidae) in the Grande River, Serra do Mar State Park - Santa Virgínia Unit, São Paulo, Brazil. Braz J Bio/ 2012; 72(2): 379-388. http://dx.doi.org/10.1590/S1519-69842012000200020. PMid:22735147.

Guidelli G, Takemoto RM, Pavanelli GC. Ecologia das infrapopulações ectoparasitas das cavidades nasais de Leporinus lacustris (Anostomidae) da planície de inundação do alto rio Paraná, Brasil. Acta Sci Bio/ Sci 2009; 31(2): 209-214. http://dx.doi.org/10.4025/ actascibiolsci.v31i2.3309.

Guidelli G, Tavechio WLG, Takemoto RM, Pavanelli GC. Fauna parasitária de Leporinus lacustris e Leporinus friderici (Characiformes, Anostomidae) da planície de inundação do alto Rio Paraná, Brasil. Acta Sci Bio/ Sci 2006; 28(3): 281-290. http://dx.doi.org/10.4025/ actascibiolsci.v28i3.228.

Johnson S, Kabata Z, Nowak BF. Effects of parasitic Crustacea on hosts. In: Smit N, Bruce N, Hadfield K, editors. Parasitic Crustacea. Cham: Springer; 2019. p. 267-239. (Zoological Monographs; vol. 3). http://dx.doi.org/10.1007/978-3-030-17385-2_6.

Le Cren ED. The lenght-weight relationship and seasonal cycle in gonad weight and condition in the perch (Perca fluviatilis). $J$ Anim Ecol 1951; 20(2): 201-219. http://dx.doi.org/10.2307/1540.

Lima FS, Casali GP, Takemoto RM. Crustacea. In: Pavanelli GC, Takemoto RM, Eiras JC, editors. Parasitologia: peixes de água doce do Brasil. Maringá: Eduem; 2013. p. 371-397.

Luque JL, Poulin R. Metazoan parasite species richness in Neotropical fishes: hots pots and the geography of biodiversity. Parasitology 2007; 134(6): 865-878. http://dx.doi.org/10.1017/S0031182007002272. PMid:17291392.

Luque JL, Vieira FM, Takemoto RM, Pavanelli GC, Eiras JC. Checklist of Crustacea parasitizing fishes from Brazil. Check List 2013; 9(6): 1449-1470. http://dx.doi.org/10.15560/9.6.1449.

Malta JCO, Varella AMB. Ergasilus turucuyus sp. n. (Copepoda: Ergasilidae) das brânquias de Acestrorhynchus falcatus (Bloch, 1794) e A. falcirostris (Cuvier, 1819) (Characiformes: Characidae) da Amazônia Brasileira. Acta Amaz 1996; 26(1-2): 69-76. http://dx.doi. org/10.1590/1809-43921996261076.

Mikheev VN, Pasternak AF, Valtonen ET. Behavioural adaptations of argulid parasites (Crustacea: Branchiura) to major challenges in their life cycle. Parasit Vectors 2015; 8(1): 394. http://dx.doi.org/10.1186/s13071-015-1005-0. PMid:26205259.

Milligan GW, Cooper MC. Methodology review: clustering methods. App/ Psychol Meas 1987; 11(4): 329-354. http://dx.doi. org/10.1177/014662168701100401.

Poulin R, Morand S. Parasite biodiversity. Washington: Smithsonian Institute Scholarly Press; 2004.

Rohde K, Hayward C, Heap M. Aspects of the ecology of metazoan ectoparasites of marine fishes. Int J Parasitol 1995; 25(8): 945-970. http://dx.doi.org/10.1016/0020-7519(95)00015-T. PMid:8550295.

Sá-Oliveira JC, Vasconcelos HCG, Pereira SWM, Isaac-Nahum VJ, Teles-Junior AP. Caracterização da pesca no Reservatório e áreas adjacentes da UHE Coaracy Nunes, Ferreira Gomes, Amapá-Brasil. Biota Amazôn 2013; 3(3): 83-96. http://dx.doi.org/10.18561/21795746/biotaamazonia.v3n3p83-96.

Tavares-Dias M, Dias-Júnior MBF, Florentino AC, Silva LMA, Cunha AC. Distribution pattern of crustacean ectoparasites of freshwater fish from Brazil. Braz J Vet Parasito/ 2015; 24(2): 136-147. http://dx.doi.org/10.1590/S1984-29612015036. PMid:26154954.

Van Name WG. The American land and fresh-water isopod Crustacea. Bull Am Mus Nat Hist 1936; 71: 1-535.

Vasconcelos HCG, Tavares-Dias M. Host-parasite interaction between crustaceans of six fish species from the Brazilian Amazon. Acta Sci Biol Sci 2016; 38(1): 113-123. http://dx.doi.org/10.4025/actascibiolsci.v38i1.29601.

Vazzoler AEAM. Biologia da reprodução de peixes teleósteos: teoria e prática. Maringá: Eduem; 1996.

Walker JG, Hurford A, Cable J, Ellison AR, Price SJ, Cressler CE. Host allometry influences the evolution of parasite host-generalism: theory and meta-analysis. Philos Trans R Soc Lond B Biol Sci 2017; 372(1719): 20160089. http://dx.doi.org/10.1098/rstb.2016.0089. PMid:28289257.

Yamada FH, Bongiovani MF, Yamada POP, Silva RJ. Parasite infracommunities of Leporinus friderici: A comparison of three tributaries of the Jurumirim Reservoir in southeastern Brazil. An Acad Bras Cienc 2017; 89(2): 953-963. http://dx.doi.org/10.1590/00013765201720160554. PMid:28489196.

Zar JH. Biostatistical analysis. 5th ed. New Jersey: Prentice Hall; 2010. 